\title{
The analysis of the impact of foreign economic policy on the development of agriculture in Russian Federation
}

\author{
Andrey Udalov ${ }^{1,2,}$, Zoya Udalova $^{3}$, Lubov Postnikova ${ }^{4}$, and Maria Kubar $^{5}$ \\ ${ }^{1}$ Don State Technical University, 1, sq. Gagarina, 344003, Rostov-on-Don, Russia \\ ${ }^{2}$ All-Russian Research Institute of Economics and Standards - branch of the "Federal Rostov Agrarian \\ Scientific Center", 52, Sokolova ave., 344006, Rostov-on-Don, Russia \\ ${ }^{3}$ Rostov State Economic University, 69, Bolshaya Sadovaya str., 344002, Rostov-on-Don, Russia \\ ${ }^{4}$ Russian State Agrarian University - Moscow Timiryazev Agricultural Academy", 58, \\ Timiryazevskaya str., 127550, Moscow, Russia \\ ${ }^{5}$ Don State Agrarian University, 24, Krivoshlykova str., 346493, Persianovsky village, Oktyabrsky \\ district, Rostov Region, Russia
}

\begin{abstract}
The article analyzed the impact of foreign economic policy on the development of the Russian federal economy, considered the analysis of the commodity structure of exports and imports of the Russian Federation with the countries of far abroad and CIS countries, presented the analysis of agricultural products by farm figures in the Russian Federation for 2014 and 2018. Several trends have been proposed, which will allow to choose the correct strategy of development of Russia for the future.
\end{abstract}

\section{Introduction}

The agriculture is the basic branch of the food complex and one of the main branches of the Russian national economy. The main task of the sub-complex is to provide the population with food in sufficient quantity, as well as raw materials of the food industry of the country. Accordingly, one of the most important directions of the study is the analysis of the impact of foreign economic policy on the development of Russian agriculture during the sanctions period.

In the current conditions of economic sanctions and import substitution policy, the development of the productive potential of Russia 's agriculture plays an important role, both in the production and processing of raw materials, due to the duration of business processes, the high level of dependence on environmental conditions, and the difficulties associated with the storage and transportation of agricultural products. In this regard, the economy of market type dictates the need to use fundamentally new conceptual approaches in the development of agricultural business of our country [1].

Of course, the foreign economic policy in the field of agriculture of Russia is influenced by customs authorities. Customs authorities, acting as an institutional participant in the

\footnotetext{
*Corresponding author: Udalov717@yandex.ru
} 
international chain of supply of goods, have a direct impact on the volume and structure of foreign trade, the time and financial costs of participants in foreign economic activities and the State, ensuring national security and stability of the country 's economy [2].

The Federal Law «On the Foundations of State Regulation of Foreign Trade Activities» № 164-FL of 08.12.2003 is one of the national legal acts regulating foreign trade activities in the Russian Federation. This law defines the main objectives of the foreign trade policy of the Russian Federation, its principles, as well as the instruments of State regulation of this sphere, dividing the latter into instruments of customs-tariff and non-tariff regulation. The main purpose of state interference in foreign economic activity is considered to be ensuring the economic and political interests of the country. State regulation applies to foreign trade, international capital movement, foreign exchange and credit relations, scientific and technological exchange, international labour movement. In practice, however, almost all countries of the world use more or less protectionism, that is, legal restrictions in the form of import duties, tariffs, as well as non-tariff barriers (quotas, licenses, voluntary export restrictions, etc.).

The agro-industrial complex occupies a special place in the sanctions confrontation between Russia and countries that have applied political and economic restrictions on it. Its development was influenced both by anti-Russian sanctions against "non-agricultural" sectors of the economy (indirectly) and by the retaliatory Russian food embargo (directly) [3].

The agricultural import ban that Russia imposed in August 2014 against the United States, EU, Norway, Australia, and Canada covered meat (beef, pork, poultry), milk, cheese, other dairy products, fish and other seafood, fruit, vegetables, nuts, and many processed foods. Although initially created for just one year, the ban was renewed (again officially for one year) in both 2015 and 2016, and in 2017 extended through 2018 [4].

Since 2014, the Russian Federation has lost about $60 \%$ of meat and fish imports and about $50 \%$ of dairy, vegetable and fruit imports, which has created enormous opportunities for domestic producers.

Import embargo to certain countries encouraged some Russian producers to closely consider the import substitution. In this regard, vegetable growing and production of processed plant products in Russia has become quite popular field of trade [5].

The effect of the situation did not keep itself waiting long. Over the past 4 years, the production of grain, pork, poultry meat, cheese, oil, etc., has grown. In the agro-industrial complex it is possible to observe an investment breakthrough: greenhouse, pig farms are being built, apple gardens, vineyards are being planted, land is being prepared for planting areas, agricultural holdings are being created.

At the same time, it is worth noting the results of the import substitution program, which have already borne fruit. "Agriculture made an incredible leap, which was difficult to imagine: sales volumes to the external market increased 16 times, simply incredible," - said V.V. Putin [6].

In Russia, import substitution is taking place for many goods, the import of which has stopped due to sanctions. Even those goods that have not previously been produced in Russia are imported. Thus, in Sverdlovsk region began production of meat delicacies hamon. The beginning of production of parmesan cheese in Tatarstan, camamber and mascarpone in Altai, mozzarella in the Orenburg region was also reported.

In 2015, in Vladikavkaz, the capital of North Ossetia, began to produce Italian cheeses mozzarella and ricotta. In July 2015, the first production of delicate grape snail meat in Russia was opened in the Komenskiy district of the Moscow region.

In 2014, Russian producers compensated about $60 \%$ of meat imports released due to food em-bargo (a total of 670,000 tons were released). Production of own meat and milk continues to grow; Cheese production in Russia in 2014 increased by almost $15 \%$, and in 
January 2015 by another 35\%. In 2015 Russia produced 1.545 million tons of meat products, which is $15.2 \%$ higher compared to the same period last year [7].

Import substitution in agriculture and in the food industry is one of the main advantages of the sanctions war. Embargoes on a number of European products, together with state support, allowed domestic producers to breathe more freely. As a result, agriculture has become a real driver of the Russian economy: in $2016,4.8 \%$ growth is observed, and in 2017 the growth was $2.8 \%$ [8].

In general for the beginning of 2019 process of import substitution goes average rates, but obviously insufficient for providing the country with all necessary. Producers, who believed that they would provide Russia with everything necessary, were unable to implement this in practice, although at times they increased the production of goods. For this reason, there has been a slight decline in the quality of products, which in most cases have traditionally been supplied from abroad.

The fact that the imposition of sanctions and the related subsidization of Russian agriculture had an impact on the increase in the performance of a large agricultural producer had not solved other global industries. Such problems include:

1) High credit of agricultural enterprises is a direct threat to food security. In order to solve this problem, it is necessary to reduce rates on loans for agriculture, including the participation of our State in the WTO. In the European Union, agricultural producers take loans at $1-2 \%$, domestic enterprises take loans at $6-7 \%$, while credit funds are issued at $22 \%$, but at the expense of state support $14 \%$ of debt is extinguished. The level of profitability of agricultural production is at the level of 4-5\%. As a result, enterprises of the agro-industrial complex remain in debt;

2) Russia 's total dependence on the West in the seed sector (dependence up to $96 \%$ ) and poultry cross-country (parental herds of chickens are mainly imported from abroad).

The decision on Russia's accession to the WTO was hailed by scientists and businessmen from the agribusiness sphere as extremely negative in terms of the consequences for Russian agriculture, particularly livestock breeding. Food import restrictions imposed by the EU countries were seen as an opportunity for the import substitution implementation policy in the Russian food sector. What are the real terms and conditions for ensuring Russia's food security? How do the implemented state foreign trade policy measures affect the import substitution process? Will additional state agriculture support measures help achieve food security? These are the questions that need to be answered from the perspective of economic science and practice [9].

\section{Methods}

In scientific publications devoted to the study of the influence of foreign economic policy on the development of agriculture and methods of state regulation of the agricultural sector, instruments of state financial support for agriculture and measures of the state foreign trade policy in the food sector are usually considered separately, as independent objects of research. [10].

As an example, Table 1 provides an analysis of agricultural production by category in the Russian Federation for 2014 and 2018. That is, we can trace the dynamics of agricultural production from the moment of imposition of sanctions until the end of 2018 .

Table 1. Analysis of agricultural products by farm category in the Russian Federation for 2014 and 2018, billion rubles [11]

\begin{tabular}{|l|c|c|c|}
\hline \multicolumn{1}{|c|}{ Indicators } & $\mathbf{3 1 . 1 2 . 2 0 1 4}$ & $\mathbf{3 1 . 1 2 . 2 0 1 8}$ & $\begin{array}{c}\text { Growth rate 2018- } \\
\mathbf{2 0 1 4 .} \%\end{array}$ \\
\hline Farms of all categories & 4319.0 & 5119.8 & 18.5 \\
\hline Agricultural products &
\end{tabular}




\begin{tabular}{|c|c|c|c|}
\hline \multicolumn{4}{|l|}{ including: } \\
\hline crop production & 2222.4 & 2569.0 & 15.6 \\
\hline livestock production & 2096.6 & 2550.8 & 21.7 \\
\hline \multicolumn{4}{|c|}{ Agricultural organizations } \\
\hline Agricultural products & 2139.0 & 2819.6 & 31.8 \\
\hline \multicolumn{4}{|l|}{ including: } \\
\hline crop production & 974.1 & 1287.3 & 32.2 \\
\hline livestock production & 1164.9 & 1532.3 & 31.5 \\
\hline \multicolumn{4}{|l|}{ Peasant farms } \\
\hline Agricultural products & 429.7 & 612.5 & 42.5 \\
\hline \multicolumn{4}{|l|}{ including: } \\
\hline crop production & 330.4 & 471.0 & 42.6 \\
\hline livestock production & 99.3 & 141.5 & 42.5 \\
\hline \multicolumn{4}{|l|}{ Farms of the population } \\
\hline Agricultural products & 1750.3 & 1687.7 & -3.6 \\
\hline \multicolumn{4}{|l|}{ including: } \\
\hline crop production & 917.9 & 810.7 & -11.7 \\
\hline livestock production & 832.4 & 877.0 & 5.4 \\
\hline
\end{tabular}

Based on the data of Table 1, it should be noted that among all categories of farms the largest increase in agricultural production in 2018 compared to 2014 is observed for peasant (farm) farms $(42.5 \%)$. For the farms of the population there is a negative dynamics - the decrease in the volume of production amounted to $3.6 \%$. This is primarily due to the decrease in the number of farms of the population as a whole in the country due to their integration into larger farms. Among farms of all categories there is an increase in the volume of agricultural output by $18.5 \%$.

According to the Ministry of Agriculture of the Russian Federation, the most positive direction in 2018 was the grain complex. Although the grain harvest in 2018 was less than a year earlier (according to Rosstat, last year farmers collected 113.3 million tons of grain in net weight, in 2017 - record 135.5 million tons), it was still higher than the average for the last five years.

At the same time following the results of last agricultural year (lasted from 01.07.2017 to 30.06.2018) Russia exported 52.422 million tons of grain, including 40.449 million tons of wheat. So far this is the maximum indicator in the history of the country, and the Russian Federation has set records for grain deliveries abroad for several seasons in a row. As a result, Russia ranked first in the world in wheat exports last agricultural year, beating both the United States and the European Union. According to the media, in 2018 more than 38.6 million tons of grain were exported through the seaports of Krasnodar Territory, which is 6.2 million tons, or $19 \%$ more than in 2017. The main recipients of grain from Cuban ports were Egypt, Sri Lanka, Saudi Arabia, Bangladesh, UAE, Indonesia, Sudan, Vietnam, Turkey and Nigeria.

According to the data of the Ministry of Agriculture of the Russian Federation, the total export of cereals from Russia in 2018 - 2019 agricultural year (from July 1, 2018 to June 30,2019 ) made 43.3 million tons, wheat - 35.2 million tons. According to forecasts of the Ministry of Agriculture of the Russian Federation, in 2019-2020 agricultural year export of grain will make 45 million tons of Russia, including 36 million tons of wheat [12].

It should be noted that import substitution in agriculture and the food industry is one of the main advantages of the sanctions war. The embargo on a number of European products, combined with existing state support, allowed domestic producers to breathe more freely.

The import substitution program also worked in animal husbandry. According to the Ministry of Agriculture, the share of imports in pork consumption in Russia decreased by three times, and poultry meat - by 2.5 times. Moreover, there is overburdening, so farmers are urgently looking for foreign markets. Thanks to successful negotiations, such markets 
are in place. Thus, according to the latest data, Japan opened its market for Russian meat. Negotiations are also under way with China [13].

On agricultural exports, Russia began to earn one third more than on arms exports. Thus, this year the export of agricultural goods will amount to 25 billion dollars (compared to 20 billion dollars in 2017). While arms exports amount to $\$ 16$ billion. We will support the development of infrastructure in the field of agriculture and exports. We specifically allocate about 400 billion rubles for this in the coming years - the development of ports, roads and so on, financial export support"- said the President [13].

In addition, the growth of the domestic agro-industry was influenced by the global market conditions - the increase in world prices for agricultural products and the increase in demand for food and biofuels from Asian consumers. Measures of state support and improvement of quality of production have played a role. For example, in crop production up to $90 \%$ of growth is directly related to the increase in yield and only $10 \%$ was determined by the increase in sown areas [14].

One of the reasons for the success of livestock production is the growth of the domestic market, on which this sector of agriculture depends directly. At the same time, export is a deterrent, as due to the high price of Russian products it is difficult to withstand competition with foreign analogues. The establishment of meat supplies to China, where its quality is appreciated, is promising, but the authorities have not yet been able to remove the existing restrictions. Therefore, so far, the real driver of livestock growth is the expansion of meat production processing, which will allow to increase production volumes.

Over the past few years, major investment flows have been changing. Previously, capital was directed primarily to such industries as pig farming, poultry farming and greenhouse farming. Due to the fact that these industries are already quite saturated and at present they can be more actively included in the scheme of investment of milk production, fruit and berry products, vegetable oil and sunflower seeds.

In order for agriculture to continue to be a growth point for the entire national economy, it is necessary to promote the export component for agricultural products. In the May decree [15] V. Putin outlined the priority goal - to increase the volume of exports of agroindustry products by 2024 to the level of 45 billion dollars. In order to implement this task, the state intends to provide 500 billion rubles. The Ministry of Agriculture believes that in order to implement the presidential decree it is necessary to organize large-scale production of products with high added value. Among them are drinks, deep grain processing products, sausage and confectionery.

Another driver of growth of domestic agro-industrial complex can be increase of real incomes of the population and increase of consumer demand, including for expensive segments of products. However, these factors are directly related to the economic situation.

\section{Results}

At the moment, foreign economic policy is limited to sanctions against the Russian Federation, which are limited to one calendar year, however, no one can predict what to expect in 2020 and in subsequent years - easing tensions or tightening trade prohibitions. Every farmer today makes a key decision about his future, the result of which can be understood only after time. It is almost impossible to predict further developments by $100 \%$, but it is possible to try to note several trends that will allow to choose the correct development strategy.

Firstly, EU economic sanctions have no effect on crops, but have a strong impact on food markets. It is necessary to understand that in today 's Russia the potential of the agricultural sector is not fully revealed. There is a huge amount of useful land. On the other 
hand, if all land is returned to circulation and production is increased, prices will fall, which is extremely unfavourable to entrepreneurs of the agricultural sector.

Secondly, without exports, Russian agriculture simply will not survive. At the same time, this year it is impossible to share Russian and Ukrainian port infrastructure for export. At the same time, imports from EU countries for most products will replace imports from other countries. In today 's logistics environment, distance no longer plays a key role as a couple decades ago.

Thirdly, it is worth noting that the main problem of imposing sanctions on farmers lies not in the prohibition of trade, but in the banking sector. The vast majority of agricultural entrepreneurs use loans and loans for future crops. Due to the tightening conditions in the banking sector, it became almost unrealistic to get long-term loans at favorable interest rates.

Fourthly, the issue of equipment is acute. Farms and the agricultural sector are regular customers of soil processing equipment. However, Russian equipment is not yet $100 \%$ capable of replacing foreign analogues, despite the presence of a number of plants with modern production capacities. If in terms of service and maintenance Russian manufacturers are already able to compete almost equally with leading Western companies, in terms of product quality domestic specialists still need to make a big leap forward. Unfortunately, at the moment in terms of reliability domestic developments are significantly inferior to foreign equipment [6].

Table 2 provides an analysis of the commodity structure of Russian Federation exports with foreign countries and CIS countries (including trade with Belarus and Kazakhstan) for 2012, 2014, 2018.

Having analyzed the commodity structure of Russian exports with foreign countries for 2012, 2014, 2018, the following main trends can be identified:

- the value of exports of food and agricultural raw materials (except textile) increased in 2018 , compared to 2012 by $59.06 \%$, compared to 2014 - by $43.77 \%$ (in 2014 compared to 2012 there is also an increase of $10.63 \%$ );

- the value of export of fuel and energy goods decreased in 2018 in comparison with 2012 by $18.17 \%$, in comparison with 2014 - for $15.87 \%$ (2014 - 2012 - decrease by $2.74 \%$ );

- the value of export of products of chemical industry, rubber decreased in 2018 in comparison with 2012 by $17.88 \%$, in comparison with 2014 - for $7.27 \%$ (2014 - 2012 decrease by $11.44 \%$ );

- the value of export of machinery, equipment and vehicles increased in 2018 by $19.15 \%$ compared to 2012 , in comparison with 2014 - by $20.81 \%$ (2014 - 2012 - decrease by $1.38 \%)$;

- the value of exports of wood and pulp and paper products in 2018 increased by $46.96 \%$ compared to 2012 , compared to 2014 - by $28.10 \%$ (2014 - 2012 - decrease by $14.72 \%)$

The following changes occurred in the commodity structure of exports to CIS countries during the period 2012, 2014, 2018:

- the value of export of food products and agricultural raw materials (except textile) grew in 2018 in comparison with 2012 by $22.06 \%$, in comparison with 2014 was reduced by $1.50 \%(2014-2012$ growth by $23.91 \%)$;

- the value of fuel and energy exports decreased in 2018 by $54.31 \%$ compared to 2012 , and in comparison with 2014 by $29.82 \%$ (2014-2012 decrease by $34.90 \%$ );

- the value of exports of products of chemical industry, rubber decreased in 2018 by $1.89 \%$ compared to 2012 , and in comparison with 2014 by $1.87 \%$ (2014-2012 decrease by $0.01 \%)$;

- the value of export of machinery, equipment and vehicles decreased by $5.21 \%$ compared to 2012, and by $5.79 \%$ compared to 2014 (growth by $0.61 \%$ in $2014-2012$ ); 
- the value of exports of wood and pulp and paper products increased by $5.74 \%$ compared to 2012 , decreased by $8.34 \%$ compared to 2014 (15.36\% growth in 2014-2012).

In recent years, there has been a tendency to change the structure of the ex-port of agricultural products in the direction of decline with a slight change in export directions for certain commodity and commodity categories of agricultural products [16].

Table 3 analyses the commodity structure of imports of the Russian Federation with foreign countries and CIS countries (taking into account trade with Belarus and Kazakhstan) for 2012, 2014, 2018.

The analysis of the commodity structure of imports from foreign countries during the period under review showed:

- imports of goods in value terms by the end of 2018 decreased by $22.15 \%$ compared to 2012 , by $16.54 \%$ - compared to 2014 ;

- the value of imports of food and agricultural raw materials (except textile) decreased in 2018 by $32.82 \%$ compared to 2012 , compared to 2014 by $30.27 \%$ (2014-2012 decrease by $3.66 \%$;

- in 2018, compared to 2012, there was a sharp decrease in imports of products for the following product groups: wood and pulp and paper products - by $34.58 \%$; Fuel and energy products - by $34.28 \%$; Machinery, equipment and vehicles - by $24.33 \%$;

- in the period from 2014 to 2018 import reduction continues in value terms for all commodity groups.

The analysis of the commodity structure of imports from CIS countries for 2012, 2014, 2018 made it possible to draw the following conclusions:

- the value of imports of food and agricultural raw materials (except textile) increased by $21.84 \%$ in 2018 compared to 2012 , by $4.27 \%$ compared to 2014 (16.85\% growth in 2014-2012);

- the cost volume of import of fuel and energy goods decreased in 2018 in comparison with 2012 by $50.72 \%$, in comparison with 2014 - for $59.08 \%$ (2014-2012 increase by $20.42 \%$ );

- imports of machinery, equipment and vehicles also fell sharply in 2018 - by almost $65 \%$ compared to $2012 ; 33.58 \%$ compared to 2014 ; Wood and paper products - by more than $41.0 \%$;

- in the period 2014-2018 there was an increase in imports of chemical industry products, rubber, textiles and footwear, as well as leather raw materials, fluff and their products by $2.36 \%, 18.40 \%$ and $172.28 \%$, respectively.

Table 2. Analysis of commodity structure of Russian Federation exports with foreign countries and CIS countries (including trade with Belarus and Kazakhstan) for 2012, 2014, 2018, thousands of US dollars [17].

\begin{tabular}{|c|c|c|c|c|c|c|c|c|c|c|c|}
\hline \multirow{3}{*}{$\begin{array}{c}\text { The } \\
\text { code } \\
\text { of } \\
\text { CN } \\
\text { FE } \\
\text { A }\end{array}$} & \multirow{3}{*}{$\begin{array}{l}\text { Name of } \\
\text { the } \\
\text { commodity } \\
\text { industry }\end{array}$} & \multirow{2}{*}{\multicolumn{3}{|c|}{ Foreign countries }} & \multirow{2}{*}{\multicolumn{3}{|c|}{ CIS countries }} & \multicolumn{4}{|c|}{ Growth rate. \% } \\
\hline & & & & & & & & \multicolumn{2}{|c|}{$\begin{array}{c}\text { Foreign } \\
\text { countries }\end{array}$} & \multicolumn{2}{|c|}{$\begin{array}{c}\text { CIS } \\
\text { countries }\end{array}$} \\
\hline & & $\begin{array}{c}31.12 .2 \\
012\end{array}$ & $\begin{array}{c}31.1 \\
2.20 \\
14\end{array}$ & $\begin{array}{c}31.12 .2 \\
018\end{array}$ & $\begin{array}{c}31.12 .2 \\
012\end{array}$ & $\begin{array}{c}\text { 31.12.2 } \\
014\end{array}$ & $\begin{array}{c}\text { 31.12.2 } \\
018\end{array}$ & $\begin{array}{c}20 \\
18- \\
20 \\
12\end{array}$ & $\begin{array}{c}20 \\
18- \\
20 \\
14\end{array}$ & $\begin{array}{c}20 \\
18- \\
20 \\
12 \\
\end{array}$ & $\begin{array}{l}20 \\
18- \\
20 \\
14\end{array}$ \\
\hline $\begin{array}{l}01- \\
24\end{array}$ & $\begin{array}{l}\text { Food and } \\
\text { agricultural } \\
\text { raw } \\
\text { materials } \\
\text { (except } \\
\text { textiles) } \\
\end{array}$ & $\begin{array}{l}12502 \\
504.30\end{array}$ & $\begin{array}{l}13 \\
831 \\
311 . \\
00\end{array}$ & $\begin{array}{l}19885 \\
918.60\end{array}$ & $\begin{array}{l}4095 \\
563.20\end{array}$ & $\begin{array}{l}5074 \\
911.70\end{array}$ & $\begin{array}{l}4998 \\
985.20\end{array}$ & $\begin{array}{l}59 . \\
06\end{array}$ & $\begin{array}{l}43 . \\
77\end{array}$ & $\begin{array}{l}22 . \\
06\end{array}$ & $\begin{array}{l}- \\
1.5 \\
0\end{array}$ \\
\hline $\begin{array}{l}25- \\
27\end{array}$ & $\begin{array}{l}\text { Mineral } \\
\text { products }\end{array}$ & $\begin{array}{l}330 \\
796 \\
179.30\end{array}$ & $\begin{array}{l}321 \\
178 \\
055 . \\
60\end{array}$ & $\begin{array}{l}270801 \\
169.30\end{array}$ & $\begin{array}{l}43761 \\
478.20\end{array}$ & $\begin{array}{l}28938 \\
209.00\end{array}$ & $\begin{array}{l}20733 \\
865.90\end{array}$ & $\begin{array}{l}- \\
18 . \\
14\end{array}$ & $\begin{array}{l}- \\
15 . \\
69\end{array}$ & $\begin{array}{l}- \\
52 . \\
62\end{array}$ & $\begin{array}{l}- \\
28 . \\
35\end{array}$ \\
\hline
\end{tabular}




\begin{tabular}{|c|c|c|c|c|c|c|c|c|c|c|c|}
\hline 27 & $\begin{array}{l}\text { Fuel and } \\
\text { energy } \\
\text { goods }\end{array}$ & $\begin{array}{l}326 \\
463 \\
029.30\end{array}$ & $\begin{array}{l}317 \\
508 \\
200 . \\
70\end{array}$ & $\begin{array}{l}267133 \\
092.80\end{array}$ & $\begin{array}{l}42915 \\
742.00\end{array}$ & $\begin{array}{l}27936 \\
394.30\end{array}$ & $\begin{array}{l}19606 \\
696.90\end{array}$ & $\begin{array}{l}- \\
18 . \\
17\end{array}$ & $\begin{array}{l}- \\
15 . \\
87\end{array}$ & $\begin{array}{l}- \\
54 . \\
31\end{array}$ & $\begin{array}{l}- \\
29 . \\
82\end{array}$ \\
\hline $\begin{array}{l}28- \\
40\end{array}$ & $\begin{array}{l}\text { Chemical } \\
\text { products. } \\
\text { rubber }\end{array}$ & $\begin{array}{l}24919 \\
264.30\end{array}$ & $\begin{array}{l}22 \\
068 \\
811 . \\
70\end{array}$ & $\begin{array}{l}20463 \\
361.40\end{array}$ & $\begin{array}{l}7051 \\
931.40\end{array}$ & $\begin{array}{l}7050 \\
924.40\end{array}$ & $\begin{array}{l}6918 \\
952.80\end{array}$ & $\begin{array}{l}- \\
17 . \\
88\end{array}$ & $\begin{array}{l}- \\
7.2 \\
7\end{array}$ & $\begin{array}{l}- \\
1.8 \\
9\end{array}$ & $\begin{array}{l}- \\
1.8 \\
7\end{array}$ \\
\hline $\begin{array}{l}41- \\
43\end{array}$ & $\begin{array}{l}\text { Leather raw } \\
\text { materials. } \\
\text { pushnina } \\
\text { and their } \\
\text { products }\end{array}$ & $\begin{array}{l}424 \\
816.00\end{array}$ & $\begin{array}{l}348 \\
282 . \\
80\end{array}$ & $\begin{array}{l}189 \\
597.50\end{array}$ & $\begin{array}{l}75 \\
012.50\end{array}$ & $\begin{array}{l}65 \\
485.20\end{array}$ & $\begin{array}{l}65 \\
277.00\end{array}$ & $\begin{array}{l}- \\
55 . \\
37\end{array}$ & $\begin{array}{l}- \\
45 . \\
56\end{array}$ & $\begin{array}{l}- \\
12 . \\
98\end{array}$ & $\begin{array}{l}- \\
0.3 \\
2\end{array}$ \\
\hline $\begin{array}{l}44- \\
49\end{array}$ & $\begin{array}{l}\text { Wood and } \\
\text { paper } \\
\text { products }\end{array}$ & $\begin{array}{l}7845 \\
359.20\end{array}$ & $\begin{array}{l}9 \\
000 \\
380 . \\
20 \\
\end{array}$ & $\begin{array}{l}11529 \\
711.60\end{array}$ & $\begin{array}{l}2283 \\
328.40\end{array}$ & $\begin{array}{l}2634 \\
059.50\end{array}$ & $\begin{array}{l}2414 \\
479.30\end{array}$ & $\begin{array}{l}46 . \\
96\end{array}$ & $\begin{array}{l}28 . \\
10\end{array}$ & $\begin{array}{l}5.7 \\
4\end{array}$ & $\begin{array}{l}8.3 \\
4\end{array}$ \\
\hline $\begin{array}{l}50- \\
67\end{array}$ & $\begin{array}{l}\text { Textiles. } \\
\text { textiles and } \\
\text { footwear }\end{array}$ & $\begin{array}{l}226 \\
653.80\end{array}$ & $\begin{array}{l}291 \\
183 . \\
50 \\
\end{array}$ & $\begin{array}{l}310 \\
072.60\end{array}$ & $\begin{array}{l}512 \\
066.90\end{array}$ & $\begin{array}{l}777 \\
429.70\end{array}$ & $\begin{array}{l}891 \\
473.50\end{array}$ & $\begin{array}{l}36 . \\
80\end{array}$ & $\begin{array}{l}6.4 \\
9\end{array}$ & $\begin{array}{l}74 . \\
09\end{array}$ & $\begin{array}{l}14 . \\
67\end{array}$ \\
\hline 71 & $\begin{array}{l}\text { Precious } \\
\text { stones. } \\
\text { precious } \\
\text { metals and } \\
\text { their } \\
\text { products }\end{array}$ & $\begin{array}{l}13632 \\
795.50\end{array}$ & $\begin{array}{l}11 \\
566 \\
728 . \\
60\end{array}$ & $\begin{array}{l}9938 \\
395.30\end{array}$ & $\begin{array}{l}185 \\
438.00\end{array}$ & $\begin{array}{l}276 \\
144.30\end{array}$ & $\begin{array}{l}159 \\
138.30\end{array}$ & $\begin{array}{l}- \\
27 . \\
10\end{array}$ & $\begin{array}{l}- \\
14 . \\
08\end{array}$ & $\begin{array}{l}- \\
14 . \\
18\end{array}$ & $\begin{array}{l}- \\
42 . \\
37\end{array}$ \\
\hline $\begin{array}{l}72- \\
83\end{array}$ & $\begin{array}{l}\text { Metals and } \\
\text { their } \\
\text { products }\end{array}$ & $\begin{array}{l}37250 \\
108.80\end{array}$ & $\begin{array}{l}34 \\
044 \\
995 . \\
00\end{array}$ & $\begin{array}{l}37497 \\
009.70\end{array}$ & $\begin{array}{l}7215 \\
196.10\end{array}$ & $\begin{array}{l}6520 \\
408.60\end{array}$ & $\begin{array}{l}6969 \\
054.10\end{array}$ & $\begin{array}{l}0.6 \\
6\end{array}$ & $\begin{array}{l}10 . \\
14\end{array}$ & $\begin{array}{l}- \\
3.4 \\
1\end{array}$ & $\begin{array}{l}6.8 \\
8\end{array}$ \\
\hline $\begin{array}{l}84- \\
90\end{array}$ & $\begin{array}{l}\text { Machinery. } \\
\text { equipment } \\
\text { and } \\
\text { vehicles }\end{array}$ & $\begin{array}{l}16218 \\
614.20\end{array}$ & $\begin{array}{l}15 \\
995 \\
216 . \\
00 \\
\end{array}$ & $\begin{array}{l}19324 \\
232.40\end{array}$ & $\begin{array}{l}10271 \\
124.00\end{array}$ & $\begin{array}{l}10333 \\
606.10\end{array}$ & $\begin{array}{l}9735 \\
578.60\end{array}$ & $\begin{array}{l}19 . \\
15\end{array}$ & $\begin{array}{l}20 . \\
81\end{array}$ & $\begin{array}{l}- \\
5.2 \\
1\end{array}$ & $\begin{array}{l}- \\
5.7 \\
9\end{array}$ \\
\hline $\begin{array}{l}68- \\
70 . \\
91- \\
97 \\
\end{array}$ & $\begin{array}{l}\text { Other } \\
\text { goods }\end{array}$ & $\begin{array}{l}3495 \\
936.60\end{array}$ & $\begin{array}{l}5 \\
041 \\
270 . \\
30 \\
\end{array}$ & $\begin{array}{l}5404 \\
339.00\end{array}$ & $\begin{array}{l}1964 \\
087.40\end{array}$ & $\begin{array}{l}1907 \\
049.80\end{array}$ & $\begin{array}{l}1733 \\
082.40\end{array}$ & $\begin{array}{l}54 . \\
59\end{array}$ & $\begin{array}{l}7.2 \\
0\end{array}$ & $\begin{array}{l}- \\
11 . \\
76\end{array}$ & $\begin{array}{l}- \\
9.1 \\
2\end{array}$ \\
\hline - & TOTAL & $\begin{array}{l}447 \\
312 \\
232.00\end{array}$ & $\begin{array}{l}433 \\
366 \\
234 . \\
70\end{array}$ & $\begin{array}{l}395343 \\
807.40\end{array}$ & $\begin{array}{l}77415 \\
226.10\end{array}$ & $\begin{array}{l}63578 \\
228.30\end{array}$ & $\begin{array}{l}54619 \\
887.10\end{array}$ & $\begin{array}{l}- \\
11 . \\
62\end{array}$ & $\begin{array}{l}- \\
8.7 \\
7\end{array}$ & $\begin{array}{l}- \\
29 . \\
45\end{array}$ & $\begin{array}{l}- \\
14 . \\
09\end{array}$ \\
\hline
\end{tabular}

Table 3. Analysis of the commodity structure of imports of the Russian Federation with foreign countries and CIS countries (including trade with Belarus and Kazakhstan) for 2012, 2014, 2018, thousands of US dollars [17].

\begin{tabular}{|c|c|c|c|c|c|c|c|c|c|c|c|}
\hline \multirow{3}{*}{$\begin{array}{l}\text { The } \\
\text { code } \\
\text { of } \\
\text { CN } \\
\text { FEA }\end{array}$} & \multirow{3}{*}{$\begin{array}{c}\text { Name of } \\
\text { the } \\
\text { commodi } \\
\text { ty } \\
\text { industry }\end{array}$} & \multirow{2}{*}{\multicolumn{3}{|c|}{ Foreign countries }} & \multirow{2}{*}{\multicolumn{3}{|c|}{ CIS countries }} & \multicolumn{4}{|c|}{ Growth rate. \% } \\
\hline & & & & & & & & \multicolumn{2}{|c|}{$\begin{array}{c}\text { Foreign } \\
\text { countries }\end{array}$} & \multicolumn{2}{|c|}{$\begin{array}{c}\text { Foreign } \\
\text { countries }\end{array}$} \\
\hline & & $\begin{array}{l}31.12 \\
.2012\end{array}$ & $\begin{array}{c}31.12 .20 \\
14\end{array}$ & $\begin{array}{c}31.12 .20 \\
18\end{array}$ & $\begin{array}{c}31.12 .2 \\
012\end{array}$ & $\begin{array}{c}31.12 .2 \\
014\end{array}$ & $\begin{array}{c}31.12 .2 \\
018\end{array}$ & $\begin{array}{c}20 \\
18- \\
20 \\
12 \\
\end{array}$ & $\begin{array}{c}20 \\
18- \\
20 \\
14\end{array}$ & $\begin{array}{c}20 \\
18- \\
20 \\
12 \\
\end{array}$ & $\begin{array}{c}201 \\
8- \\
201 \\
4\end{array}$ \\
\hline $\begin{array}{l}01- \\
24\end{array}$ & $\begin{array}{l}\text { Food and } \\
\text { agricultur } \\
\text { al raw } \\
\text { materials } \\
\text { (except } \\
\text { textiles) }\end{array}$ & $\begin{array}{l}35 \\
402 \\
662.4\end{array}$ & $\begin{array}{l}34105 \\
952.3\end{array}$ & $\begin{array}{l}23783 \\
259.7\end{array}$ & $\begin{array}{l}4799 \\
826.90\end{array}$ & $\begin{array}{l}5608 \\
778.20\end{array}$ & $\begin{array}{l}5848 \\
281.70\end{array}$ & $\begin{array}{l}- \\
32 . \\
82\end{array}$ & $\begin{array}{l}- \\
30 . \\
27\end{array}$ & $\begin{array}{l}21 . \\
84\end{array}$ & $\begin{array}{l}4.2 \\
7\end{array}$ \\
\hline $\begin{array}{l}25- \\
27\end{array}$ & $\begin{array}{l}\text { Mineral } \\
\text { products }\end{array}$ & $\begin{array}{l}2814 \\
670.0\end{array}$ & $\begin{array}{l}2160 \\
356.8\end{array}$ & $\begin{array}{l}2138 \\
863.4\end{array}$ & $\begin{array}{l}4537 \\
412.10\end{array}$ & $\begin{array}{l}5069 \\
168.30\end{array}$ & $\begin{array}{l}2834 \\
609.50\end{array}$ & $\begin{array}{l}- \\
24 . \\
01\end{array}$ & $\begin{array}{l}- \\
0.9 \\
9\end{array}$ & $\begin{array}{l}- \\
37 . \\
53\end{array}$ & $\begin{array}{l}- \\
44 . \\
08\end{array}$ \\
\hline
\end{tabular}




\begin{tabular}{|c|c|c|c|c|c|c|c|c|c|c|c|}
\hline 27 & $\begin{array}{l}\text { Fuel and } \\
\text { energy } \\
\text { goods }\end{array}$ & $\begin{array}{l}1784 \\
648.1\end{array}$ & $\begin{array}{l}1234 \\
479.8\end{array}$ & $\begin{array}{l}1172 \\
881.0\end{array}$ & $\begin{array}{l}2217 \\
498.60\end{array}$ & $\begin{array}{l}2670 \\
319.60\end{array}$ & $\begin{array}{l}1092 \\
798.90\end{array}$ & $\begin{array}{l}- \\
34 . \\
28\end{array}$ & $\begin{array}{l}- \\
4.9 \\
9 \\
\end{array}$ & $\begin{array}{l}- \\
50 . \\
72\end{array}$ & $\begin{array}{l}- \\
59 . \\
08\end{array}$ \\
\hline $\begin{array}{l}28- \\
40\end{array}$ & $\begin{array}{l}\text { Chemical } \\
\text { products. } \\
\text { rubber }\end{array}$ & $\begin{array}{l}43 \\
831 \\
781.6 \\
\end{array}$ & $\begin{array}{l}42635 \\
892.8\end{array}$ & $\begin{array}{l}39686 \\
647.0\end{array}$ & $\begin{array}{l}3876 \\
524.90\end{array}$ & $\begin{array}{l}3778 \\
768.10\end{array}$ & $\begin{array}{l}3868 \\
080.00\end{array}$ & $\begin{array}{l}- \\
9.4 \\
6 \\
\end{array}$ & $\begin{array}{l} \\
6.9 \\
2 \\
\end{array}$ & $\begin{array}{l}-\overline{-} \\
0.2 \\
2\end{array}$ & $\begin{array}{l}2.3 \\
6\end{array}$ \\
\hline $\begin{array}{l}41- \\
43\end{array}$ & $\begin{array}{l}\text { Leather } \\
\text { raw } \\
\text { materials. } \\
\text { pushnina } \\
\text { and their } \\
\text { products }\end{array}$ & $\begin{array}{l}1498 \\
299.0\end{array}$ & $\begin{array}{l}1256 \\
507.8\end{array}$ & $\begin{array}{l}1204 \\
522.1\end{array}$ & $\begin{array}{l}90 \\
287.80\end{array}$ & $\begin{array}{l}23 \\
745.80\end{array}$ & $\begin{array}{l}64 \\
655.60\end{array}$ & $\begin{array}{l}- \\
19 . \\
61\end{array}$ & $\begin{array}{l}- \\
4.1 \\
4\end{array}$ & $\begin{array}{l}- \\
28 . \\
39\end{array}$ & $\begin{array}{l}172 \\
.28\end{array}$ \\
\hline $\begin{array}{l}44- \\
49\end{array}$ & $\begin{array}{l}\text { Wood } \\
\text { and paper } \\
\text { products }\end{array}$ & $\begin{array}{l}5003 \\
071.4\end{array}$ & $\begin{array}{l}4809 \\
659.2\end{array}$ & $\begin{array}{l}3273 \\
212.7\end{array}$ & $\begin{array}{l}1077 \\
153.50\end{array}$ & $\begin{array}{l}1084 \\
343.70\end{array}$ & $\begin{array}{l}634 \\
819.40\end{array}$ & $\begin{array}{l}- \\
34 . \\
58\end{array}$ & $\begin{array}{l}31 . \\
95\end{array}$ & $\begin{array}{l}- \\
41 . \\
07\end{array}$ & $\begin{array}{l}- \\
41 . \\
46\end{array}$ \\
\hline $\begin{array}{l}50- \\
67\end{array}$ & $\begin{array}{l}\text { Textiles. } \\
\text { textiles } \\
\text { and } \\
\text { footwear }\end{array}$ & $\begin{array}{l}14 \\
763 \\
632.3\end{array}$ & $\begin{array}{l}14663 \\
923.3\end{array}$ & $\begin{array}{l}12880 \\
477.7\end{array}$ & $\begin{array}{l}2630 \\
674.90\end{array}$ & $\begin{array}{l}1641 \\
968.70\end{array}$ & $\begin{array}{l}1944 \\
151.30\end{array}$ & $\begin{array}{l}- \\
12 . \\
76\end{array}$ & $\begin{array}{l}- \\
12 . \\
16\end{array}$ & $\begin{array}{l}- \\
26 . \\
10\end{array}$ & $\begin{array}{l}18 . \\
40\end{array}$ \\
\hline 71 & $\begin{array}{l}\text { Precious } \\
\text { stones. } \\
\text { precious } \\
\text { metals } \\
\text { and their } \\
\text { products }\end{array}$ & $\begin{array}{l}627 \\
991.2\end{array}$ & $\begin{array}{l}811 \\
384.1\end{array}$ & $\begin{array}{l}581 \\
820.7\end{array}$ & $\begin{array}{l}104 \\
347.60\end{array}$ & $\begin{array}{l}295 \\
380.30\end{array}$ & $\begin{array}{l}179 \\
930.60\end{array}$ & $\begin{array}{l}- \\
7.3 \\
5\end{array}$ & $\begin{array}{l}- \\
28 . \\
29\end{array}$ & $\begin{array}{l}72 . \\
43\end{array}$ & $\begin{array}{l}- \\
39 . \\
09\end{array}$ \\
\hline $\begin{array}{l}72- \\
83\end{array}$ & $\begin{array}{l}\text { Metals } \\
\text { and their } \\
\text { products }\end{array}$ & $\begin{array}{l}15 \\
305 \\
466.3 \\
\end{array}$ & $\begin{array}{l}14429 \\
861.4\end{array}$ & $\begin{array}{l}12515 \\
387.0\end{array}$ & $\begin{array}{l}6522 \\
733.30\end{array}$ & $\begin{array}{l}4784 \\
044.60\end{array}$ & $\begin{array}{l}4540 \\
125.10\end{array}$ & $\begin{array}{l}- \\
18 . \\
23\end{array}$ & $\begin{array}{l}13 . \\
27\end{array}$ & $\begin{array}{l}- \\
30 . \\
40\end{array}$ & $\begin{array}{l}- \\
5.1 \\
0\end{array}$ \\
\hline $\begin{array}{l}84- \\
90\end{array}$ & $\begin{array}{l}\text { Machiner } \\
\mathrm{y} . \\
\text { equipmen } \\
\mathrm{t} \text { and } \\
\text { vehicles }\end{array}$ & $\begin{array}{l}141 \\
743 \\
629.2\end{array}$ & $\begin{array}{l}128136 \\
582.1\end{array}$ & $\begin{array}{l}107257 \\
582.0\end{array}$ & $\begin{array}{l}15377 \\
544.20\end{array}$ & $\begin{array}{l}8106 \\
287.00\end{array}$ & $\begin{array}{l}5384 \\
345.60\end{array}$ & $\begin{array}{l}- \\
24 . \\
33\end{array}$ & $\begin{array}{l}- \\
16 . \\
29\end{array}$ & $\begin{array}{l}- \\
64 . \\
99\end{array}$ & $\begin{array}{l}- \\
33 . \\
58\end{array}$ \\
\hline $\begin{array}{l}68- \\
70 . \\
91- \\
97\end{array}$ & $\begin{array}{l}\text { Other } \\
\text { goods }\end{array}$ & $\begin{array}{l}11 \\
258 \\
540.7\end{array}$ & $\begin{array}{l}10938 \\
058.8\end{array}$ & $\begin{array}{l}8626 \\
513.0\end{array}$ & $\begin{array}{l}1301 \\
158.90\end{array}$ & $\begin{array}{l}1641 \\
502.80\end{array}$ & $\begin{array}{l}904 \\
090.80\end{array}$ & $\begin{array}{l}- \\
23 . \\
38\end{array}$ & $\begin{array}{l}- \\
21 . \\
13\end{array}$ & $\begin{array}{l}- \\
30 . \\
52\end{array}$ & $\begin{array}{l}- \\
44 . \\
92\end{array}$ \\
\hline - & TOTAL & $\begin{array}{l}272 \\
249 \\
744.1 \\
0 \\
\end{array}$ & $\begin{array}{l}253948 \\
178.60\end{array}$ & $\begin{array}{l}211948 \\
285.30\end{array}$ & $\begin{array}{l}40317 \\
664.10\end{array}$ & $\begin{array}{l}32033 \\
987.50\end{array}$ & $\begin{array}{l}26203 \\
089.60\end{array}$ & $\begin{array}{l}- \\
22 . \\
15\end{array}$ & $\begin{array}{l}16 . \\
54\end{array}$ & $\begin{array}{l}35 . \\
01\end{array}$ & $\begin{array}{l}18 . \\
20\end{array}$ \\
\hline
\end{tabular}

In today's environment, all organizations (regardless of their form of ownership or sphere of activity) are exposed to many risk factors due to internal circumstances and the impact of the external environment. Agricultural enterprises are no exception.

Agricultural production and sales are most likely to lead to loss of profits, financial volatility and bankruptcy. This can be explained by the fact that the volume of agricultural output is influenced not only by the volume of investments, labor costs, but also by objective natural and climatic conditions and biological laws, so the investment in this sector of the economy is rather risky [18].

At the moment, all enterprises in one way or another engaged in crop production are at a crossroads. On the one hand, domestic companies have opened up a favorable environment for development in less competitive conditions. On the other hand, investing in areas of the economy characterized by long-term payback is extremely risky. In such a situation, when it is not necessary to wait for investments from individuals, the first role is public financing and subsidies. It can be assumed that financing of agriculture by the state will increase (otherwise it simply will not survive), but will be primarily turned to large holdings and projects, while small businesses will have to rely only on themselves by tradition. 


\section{Conclusion}

A logical step for the development of agriculture can be the deliberate acceleration of the implementation of a number of large agricultural projects with the involvement of bank capital. It is known that any large agrarian project passes a multi-year path of approval before implementation. With the support of the State, it is possible to accelerate this process at times, significantly simplifying implementation.

The main issue of further development of the entire agricultural complex of Russia is the activity of Asian players in the market. At the moment, Chinese and Korean companies are focusing on small local projects. However, a temporary withdrawal from the European players market could encourage Eastern neighbors to take active action and seize entire segments of the market. The current situation offers prospects for the acquisition of very large plots of land.

The overall market conditions will be influenced by the search for new suppliers for the Russian market, and the desire to circumvent possible restrictions on exports and imports. It is already clear that the volume of products from South American countries will increase. The question is only the percentage division of volumes.

With the globalization of the economy and the emergence of an unusually competitive global food market, the key factor in achieving the competitive advantage of agribusiness enterprises is the optimization of their activities through effective management decisions [19].

Thus, there is a need for a new foreign economic policy in the agricultural sector, which ensures the improvement of already existing and the elaboration of new organizational and economic mechanisms adapted to modern economic conditions for the development of various forms of agricultural management, which should not only guarantee the coherent sustainable development of all production industries, but also its coordination with the development of other key sectors and the general socio-spatial transformation of the country.

\section{References}

1. A. Udalov, Z. Udalova, D. Postnikova, L. Postnikova, IOP Conf. Ser.: Earth Environ. Sci. 403, 012148 (2019)

2. G. Goremykina, Y. Gupanova, Z. Udalova, IOP Conf. Ser.: Earth Environ. Sci. 403, 012129 (2019)

3. Russia's agro-industrial complex in the face of a "war of sanctions." Economic portal, http://institutiones.com/agroindustrial/2694-agropromyshlennyi-kompleks-rossii-vusloviyax-voiny-sankcii.html

4. W. Liefert, O. Liefert, R. Seeley, T. Lee, Journal of Eurasian Studies 10, 119-135 (2019) DOI: $10.1177 / 1879366519840185$

5. E. Avdokushin, I. Kudryashova, Foods and Raw Materials 4(2), 148-156 (2016)

6. All-Russian Forum Agricultural Producers, http://kremlin.ru/events/president/news/57035

7. Import substitution in Russia. Anti-Russian sanctions, https://ruxpert.ru/Антироссийские_санкции

8. A. Udalov, Z. Udalova, Accounting in agriculture 5, 47-54 (2019)

9. I. Boldyreva, O. Andryushchenko, A. Nikitaeva, Z. Udalova, J. Rudash, Journal of Environmental Management and Tourism 8.4(20), 642-647 (2017) 
10. D. Sedik, Z. Lerman, V. Uzun, Edition: Studies on the Agricultural and Food Sector in Transition Economies 79, 217-247 (2015)

11. Russia in numbers. 2019: statistical collection (Rosstat, Moscow, 2019)

12. Russia reduced grain export almost by a third, https://eadaily.com/ru/news/2019/07/29/rossiya-sokratila-eksport-zerna-pochti-na-tret

13. How the West forced Russia to "turn on brains", https://vz.ru/economy/2018/12/20/956438.html

14. After sanctions and embargo: how agriculture in Russia experienced a rise and one crop failure, http://kapitalrus.ru/articles/article/posle_sankcii_i_embargo_kak_selskoe_hozyaistvo_v_rossii_pere jilo_podem_i_od/

15. The May decree - 2018. The document signed by the Head of State defines the development goals of Russia until 2024, https://tass.ru/politika/5182019

16. I. Kovaleva, International Journal of Humanities and Natural Sciences 2-2, 77-81 (2019) DOI: 10.24411/2500-1000-2019-10576

17. Federal Customs Service. Customs foreign trade statistics section, http://old.customs.ru/index2.php?option=com_content\&view=article\&id=18875: 2013 $\&$ catid $=52: 2011-01-24-16-28-57 \&$ Itemid $=1978$

18. Z. Udalova, K. Burtseva, A. Alekseev, A. Udalov, IOP Conf. Ser.: Earth Environ. Sci. 403, 012130 (2019)

19. L. Khoruzhy, Y. Katkov, V. Khoruzhy, K. Dzhikiya, E. Stepanenko, Astra Salvensis VI, 835-845 (2018) 